\title{
Unraveling the Role of Vegetables in Spreading Antimicrobial-Resistant Bacteria: A Need for Quantitative Risk Assessment
}

\author{
Christina Susanne Hölzel, Julia Louisa Tetens, ${ }^{1}$ and Karin Schwaiger ${ }^{2}$
}

\begin{abstract}
In recent years, vegetables gain consumer attraction due to their reputation of being healthy in combination with low energy density. However, since fresh produce is often eaten raw, it may also be a source for foodborne illness. The presence of antibiotic-resistant bacteria might pose a particular risk to the consumer. Therefore, this review aims to present the current state of knowledge concerning the exposure of humans to antibiotic-resistant bacteria via food of plant origin for quantitative risk assessment purposes. The review provides a critical overview of available information on hazard identification and characterization, exposure assessment, and risk prevention with special respect to potential sources of contamination and infection chains. Several comprehensive studies are accessible regarding major antimicrobial-resistant foodborne pathogens (e.g., Salmonella spp., Listeria spp., Bacillus cereus, Campylobacter spp., Escherichia coli) and other bacteria (e.g., further Enterobacteriaceae, Pseudomonas spp., Gram-positive cocci). These studies revealed vegetables to be a potential — although rare-vector for extended-spectrum beta-lactamase-producing Enterobacteriaceae, mcr1-positive E. coli, colistin- and carbapenem-resistant Pseudomonas aeruginosa, linezolidresistant enterococci and staphylococci, and vancomycin-resistant enterococci. Even if this provides first clues for assessing the risk related to vegetable-borne antimicrobial-resistant bacteria, the literature research reveals important knowledge gaps affecting almost every part of risk assessment and management. Especially, the need for (comparable) quantitative data as well as data on possible contamination sources other than irrigation water, organic fertilizer, and soil becomes obvious. Most crucially, dose-response studies would be needed to convert a theoretical "risk" (e.g., related to antimicrobial-resistant commensals and opportunistic pathogens) into a quantitative risk estimate.
\end{abstract}

Keywords: ESBL, antimicrobial resistance, antibiotic resistance, foodborne pathogens, vegetables, risk assessment

\section{Introduction}

$\mathbf{V}$ EGETABLES ARE ESSENTIAL for healthy nutrition and obesity reduction in Western civilizations, due to a high nutrient density, correlated with low energy density (Darmon et al., 2005). They are defined as "a plant, root, seed, or pod that is used as food, especially in dishes that are not sweet" in the Cambridge dictionary. In 2003, WHO and FAO started an initiative to promote fruit and vegetable consumption for health worldwide, with a recommended minimum intake of $400 \mathrm{~g}$ fruits and vegetables per day (www.who.int).

However, vegetables are also implicated in foodborne outbreaks due to various-most often unknown-sources of contamination, the most recent familiar case in Europe being the enterohemorrhagic Escherichia coli (EHEC) outbreak of 2011, with 4321 reported cases, of which at least 50 had been fatal (Robert-Koch-Institute, Germany, cited from Buchholz et al., 2011). Besides other unusual features, the outbreak strain was characterized as an extended-spectrum beta-lactamase (ESBL) producer due to the presence of bla $a_{\mathrm{CTX}-\mathrm{M} 15}$ genes (Mellmann et al., 2011). The press reported extensively on antimicrobial resistance (AMR), but not on the fact that this resistance was meaningless for therapy, due to contraindication of antibiosis in EHEC infections (see Hazard Identification and Characterization section).

According to the FAO definition, quantitative risk assessment is based on four steps: hazard identification, hazard characterization, exposure assessment, and risk characterization

\footnotetext{
${ }^{1}$ Animal Hygiene and Animal Health Management, Faculty of Agricultural and Nutritional Sciences, Christian-Albrechts-University Kiel (CAU), Kiel, Germany.

${ }^{2}$ Department of Veterinary Sciences, Institute of Food Safety, Ludwig-Maximilians-University Munich (LMU), Munich, Germany.

(c) Christina Susanne Hölzel et al. 2018; Published by Mary Ann Liebert, Inc. This Open Access article is distributed under the terms of the Creative Commons Attribution Noncommercial License (http://creativecommons.org/licenses/by-nc/4.0/) which permits any noncommercial use, distribution, and reproduction in any medium, provided the original author(s) and the source are cited.
} 
(www.fao.org). In this definition, hazard identification means to identify impacts on human health and the circumstances under which the danger is present, whereas hazard characterization aims to quantitatively or qualitatively evaluate the adverse effects on human health (e.g., using dose-response relationship). Exposure assessment provides the likely degree of consumption or intake of the hazardous agent, and the risk characterization tries to offer an estimate of the likely adverse effect in the target population by integrating the first three steps.

There have been well-recognized approaches for risk assessment related to general microbial hazards imposed by vegetable consumption (Hamilton et al., 2006; Franz et al., 2010; Danyluk and Schaffner, 2011; Pang et al., 2017). However, no specific quantitative risk assessment has been published for hazards related to antimicrobial-resistant bacteria (ARB) in vegetables, although AMR is seen as an obligate "risk amplifier' in public awareness. Steps to assess specific risks due to AMR would involve all steps of quantitative risk assessment. This starts from hazard identification (i.e., is a known adverse health effect aggravated by AMR features of the causative agent? Does an adverse health effect arise from spread of antibiotic resistance features in commensals, which otherwise would not be considered as microbial hazards?) but also includes hazard characterization as well as exposure assessment.

This literature survey aims to initiate a discussion on quantitative risk assessment related to the spread of antibiotic resistance in the vegetable food chain. For this purpose, we tried to provide an overview over current screening data starting from 2007. To allow risk prevention, sources of contamination were highlighted as well. Finally, important knowledge gaps were identified, which should be addressed in the future to facilitate quantitative risk assessment within a reasonable term.

\section{Literature Search and Exclusion Criteria}

Our PubMed search combined the keywords "antimicrobial resistance" or "antibiotic resistance" with "vegetables" or "fresh produce" in May 2018. We aimed to provide a systematic overview on recent screening data for antibioticresistant bacteria isolated from vegetables, so we covered the period from January 2007 to April 2018 and found 169 studies, after excluding double hits. The search result comprised 93 studies that reported screening data for antibiotic resistance in vegetable-borne isolates (Tables 1-7). We excluded 22 obvious mishits (one study dealing with the inhibition of bladder cancer cell proliferation by mustard oil, for example) and 13 studies that did not investigate vegetableborne isolates (instead, these studies reported on, e.g., reptiles). Eight studies were excluded since they did not attribute resistant isolates to their source (these studies presented resistance rates from different sources, e.g., meat and vegetables, as one common value). We excluded opinion reports, reviews (unless they comprised relevant screening data), and publications that described modeling or method implementation or whole genome sequencing data of single isolates (in total 14 studies). We also excluded three studies in a language other than English (Polish, Ukrainian, and Chinese). One study that would not have met the exclusion criteria was excluded afterward since it presented mainly resistance data for Escherichia coli and vancomycin, a substance that is not effective in Enterobacteriaceae. All other studies presenting intrinsic resistance data (e.g., erythromycin in Salmonella spp.) were kept since significant results for acquired resistance were presented as well.

All 13 experimental studies returned by the keywords were included in the text (e.g., experimental application of manure or biosolids to soil), as were two studies that reported metagenomic screening data.

Besides our systematic approach, we used targeted searches with individual keywords to add details (e.g., on vegetable consumption).

\section{Hazard Identification and Characterization}

A recent outbreak due to vegetables was related to a multiresistant strain of EHEC O104:H4, which produced ESBL enzymes (Buchholz et al., 2011). Did this fact add adverse effects to the outbreak? In general, antibiotics are not the first-line agents for treatment of diarrhea (Guerrant et al., 2001). On the contrary, for EHEC, as compiled by Goldwater and Bettelheim (2012), antibiotics-and especially betalactams - are even contraindicated due to the fact that cellwall-impaired dead bacteria release more toxin (Tarr et al., 2005; Smith et al., 2012). Even subinhibitory concentrations are thought to increase toxin production and/or toxin release (Grif et al., 1998). Thus, in the absence of treatment indication, AMR could not lead to treatment failure. However, for other bacterial infections such as systemic listeriosis, antibiotic therapy is the treatment of choice (Safdar and Armstrong, 2003), and clinical resistance against first-line antibiotics is likely to impose additional health hazards. Centers for Disease Control and Prevention report recent cases of listeriosis in the United States due to vegetable consumption, which led to several deaths (www.cdc.gov); it is unknown whether these deaths were related to treatment failure or other reasons such as delayed diagnosis.

Providing comprehensive hazard identification of all foodborne pathogens associated with vegetables goes beyond the scope of this review. Thus, three more general situations will be exemplarily illustrated and connected to AMR: (1) primary foodborne infectious disease due to obligatory or opportunistic pathogens, (2) foodborne microbial intoxication, (3) foodborne colonization, maybe followed by opportunistic disease after a considerable time-shift (Fig. 1a-c).

Primary foodborne infectious disease is seen after infection with pathogenic serovars of, for example, Salmonella enterica subsp. enterica, Campylobacter spp., Listeria monocytogenes, Bacillus cereus, and E. coli (e.g., EHEC, Shigatoxin producing E. coli [STEC]) (Butler et al., 2015). In case of systemic infection, as already mentioned, antimicrobial treatment is often indicated (except for EHEC), and AMR to clinically relevant antimicrobial drugs will lower the number of therapeutic options (Fig. 1a). In contrast, foodborne Staphylococcus aureus exclusively causes food poisoning due to the presence of preformed heat-stable toxins independent of viable bacteria (Kadariya et al., 2014). Thus, this kind of food poisoning is self-limiting, and antibiotic treatment is never indicated (Fig. 1b). However, S. aureus might cause opportunistic infections of wounds like cuts (van de SandeBruinsma et al., 2015), which might occur during food preparation and might call for topical treatment. Only a limited number of B. cereus lineages (Ehling-Schulz et al., 


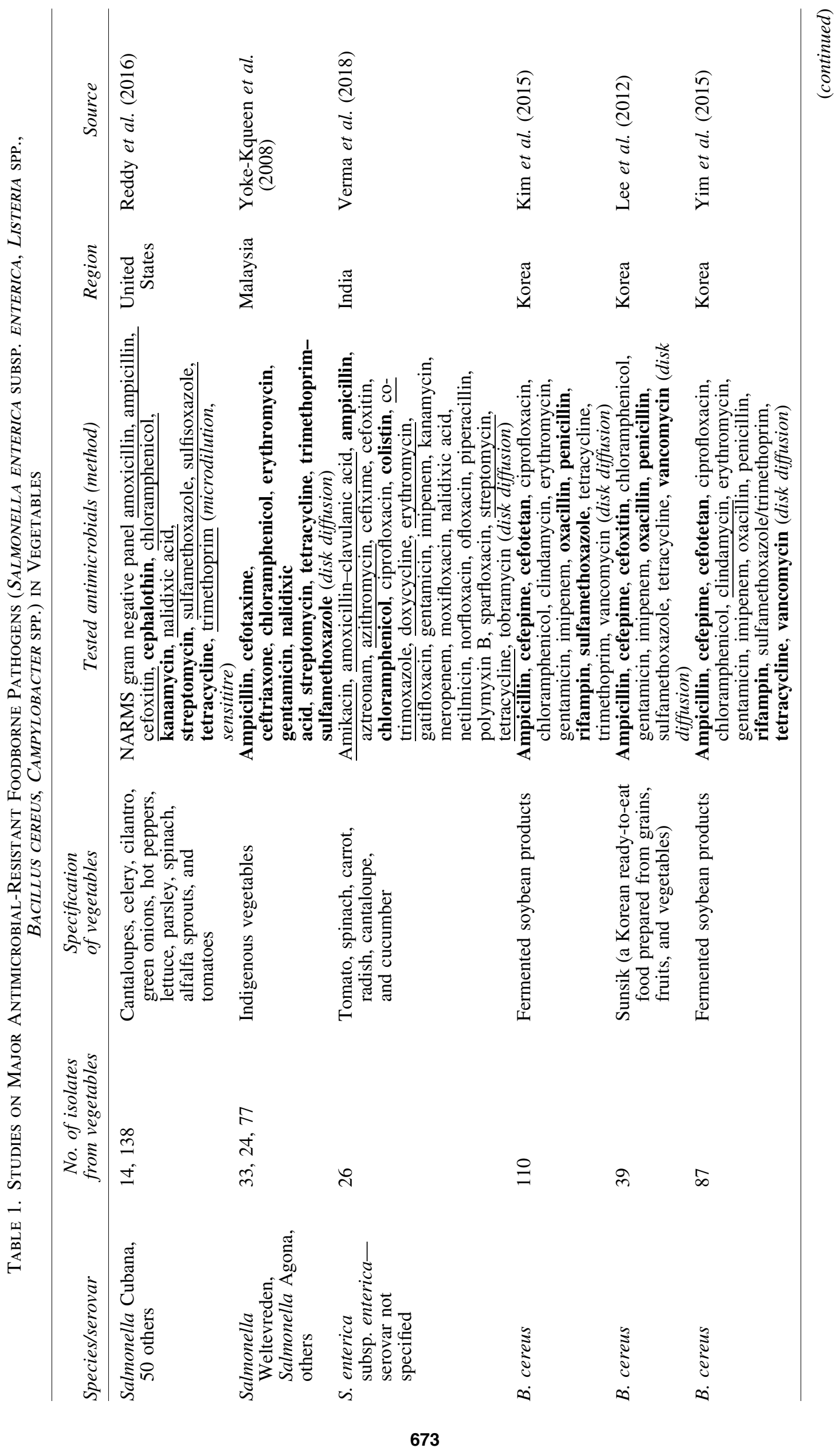




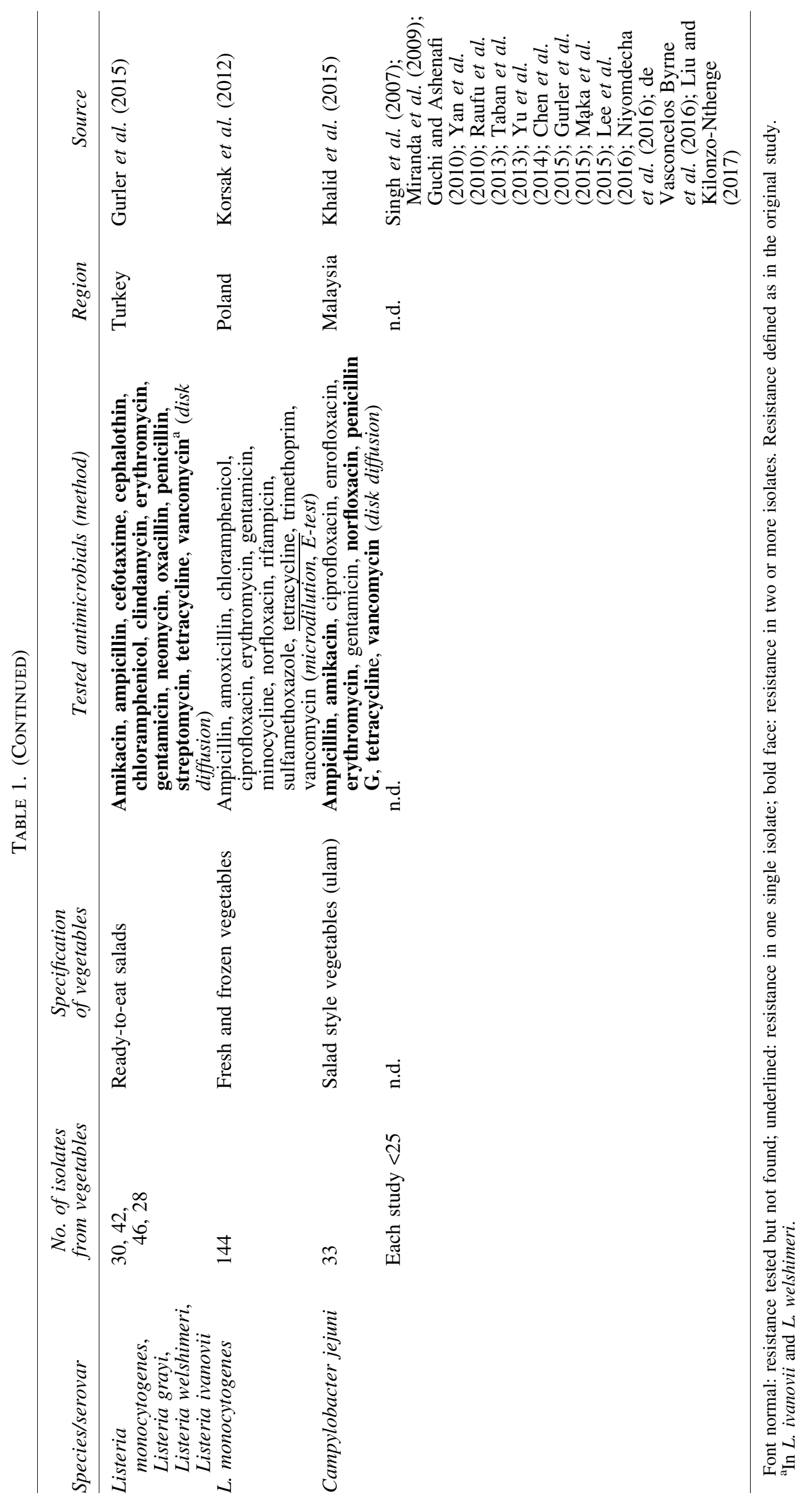




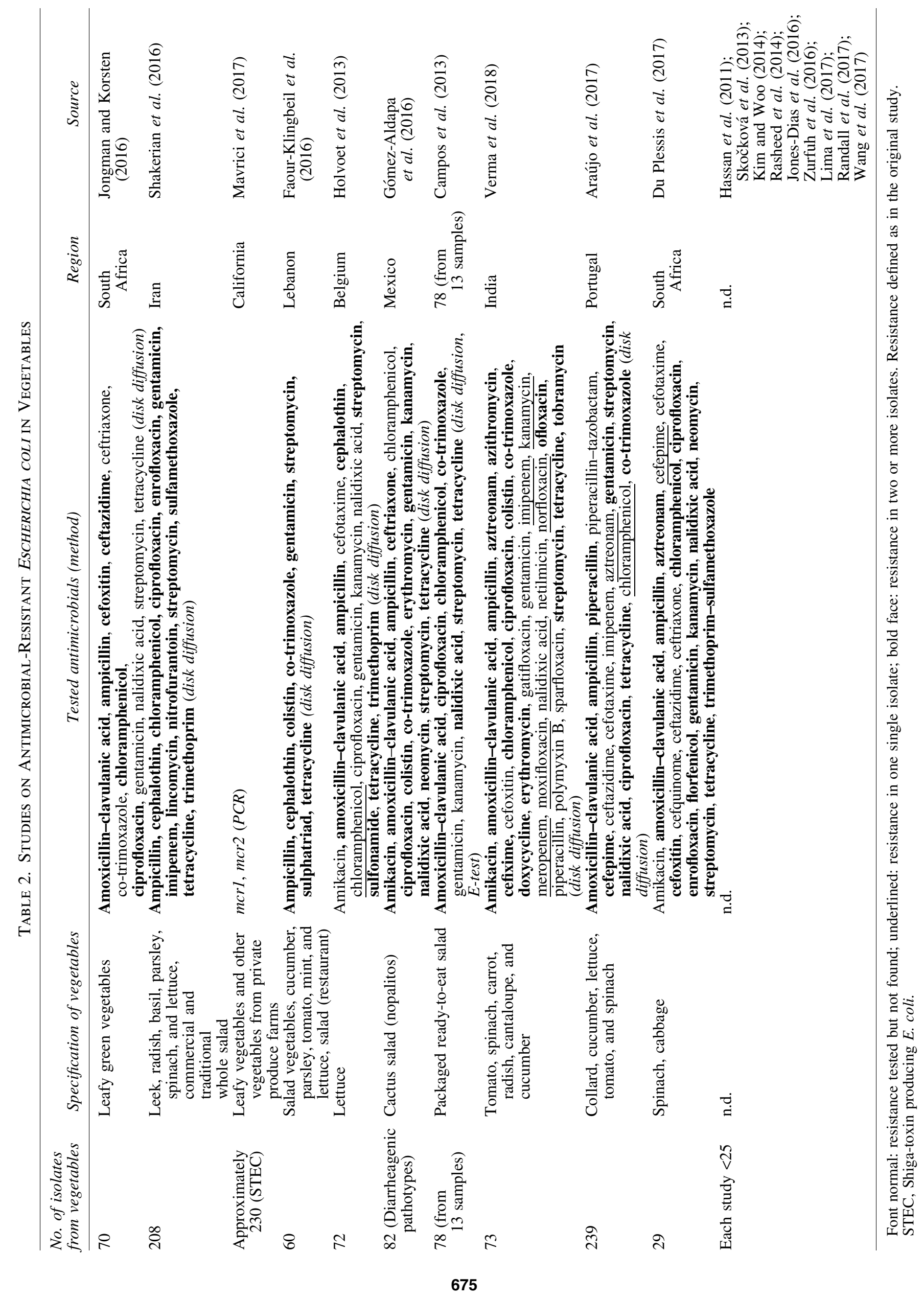


Table 3. Studies on Antimicrobial-Resistant Pseudomonads in Vegetables

\begin{tabular}{|c|c|c|c|c|c|}
\hline Species & $\begin{array}{l}\text { No. of } \\
\text { isolates } \\
\text { from } \\
\text { vegetables }\end{array}$ & Specification of vegetables & $\begin{array}{c}\text { Tested antimicrobials } \\
\text { (method) }\end{array}$ & Region & Source \\
\hline $\begin{array}{l}\text { Pseudomonas } \\
\text { aeruginosa, } \\
\text { Pseudomonas } \\
\text { putida }\end{array}$ & 295,106 & $\begin{array}{l}\text { Fruit, root, bulbous } \\
\text { vegetables, salads, and } \\
\text { cereals }\end{array}$ & $\begin{array}{l}\text { Amikacin, apramycin, } \\
\text { cefepime, ceftazidime, } \\
\text { ciprofloxacin, colistin, } \\
\text { doxycycline (only in } P \text {. } \\
\text { putida), enrofloxacin, } \\
\text { gentamicin, imipenem, } \\
\text { neomycin, netilmicin, } \\
\text { piperacillin+tazobactam, } \\
\text { streptomycin, tobramycin, } \\
\text { (microdilution) }\end{array}$ & Germany & $\begin{array}{l}\text { Schwaiger et al. } \\
\text { (2011a) }\end{array}$ \\
\hline P. aeruginosa & 88 & $\begin{array}{l}\text { Lettuce, white cabbage, } \\
\text { red cabbage, carrots, } \\
\text { sweet pepper, cucumber, } \\
\text { and tomatoes, mixed }\end{array}$ & $\begin{array}{l}\text { Ampicillin, aztreonam, } \\
\text { ceftazidime, } \\
\text { chloramphenicol, } \\
\text { ciprofloxacin, gentamicin, } \\
\text { imipenem, } \\
\text { sulfamethoxazole- } \\
\text { trimethoprim, } \\
\text { tetracycline (disk } \\
\text { diffusion) }\end{array}$ & Jamaica & $\begin{array}{l}\text { Allydice-Francis } \\
\text { and Brown } \\
(2012)\end{array}$ \\
\hline \multirow[t]{2}{*}{$\begin{array}{l}\text { Pseudomonas } \\
\text { spp. }\end{array}$} & 35 & $\begin{array}{l}\text { Leaf lettuces, tomatoes, } \\
\text { and carrots }\end{array}$ & $\begin{array}{l}\text { Amikacin, cefepime, } \\
\text { cefotaxime, ceftazidime, } \\
\text { ciprofloxacin, imipenem, } \\
\text { gentamicin (disk diffusion) }\end{array}$ & Portugal & $\begin{array}{l}\text { Jones-Dias et al. } \\
\text { (2016) }\end{array}$ \\
\hline & $\begin{array}{l}\text { Each study } \\
\quad<25\end{array}$ & n.d. & n.d. & n.d. & $\begin{array}{l}\text { Bezanson et al. } \\
\text { (2008); Hassan } \\
\text { et al. (2011); } \\
\text { Estepa et al. } \\
\text { (2015) }\end{array}$ \\
\hline
\end{tabular}

Font normal: resistance tested but not found; underlined: resistance in one single isolate; bold face: resistance in two or more isolates. Resistance defined as in the original study.

2005) are able to cause mere food poisoning due to the presence of cereulide (see Rosenquist et al., 2005, for example). Instead, in most cases, B. cereus needs to infect the organism to cause gastrointestinal disease (due to synthesis of Nhe and other enterotoxins in the intestine; EFSA, 2016). This is similar to the situation seen in Clostridium perfringens (Uzal et al., 2014). Antibiotic treatment of B. cereus infections is recommended in severe disease, whereas it is unreasonable in self-limited food poisoning (Spiliopoulou et al., 2014). C. perfringens might contribute to antibioticassociated diarrhea (Borriello et al., 1984; Kim et al., 2017b); treatment of choice is discontinued primary antibiosis; only severe cases might be treated with glycopeptides or metronidazole (Bergogne-Bérézin, 2000).

A particular situation is found for organisms that are able to colonize the human gastrointestinal tract (Fig. 1c), such as E. coli or enterococci. These bacteria are useful indicators for AMR (Franklin et al., 2001; Schwaiger et al., 2011b) and were included in a recent EFSA recommendation to provide harmonized European monitoring of AMR (EFSA, 2012), as authorized by Directive 2003/99/EC. In addition, E. coli might produce ESBL enzymes, and this ESBL production (or other resistance phenotypes) might complicate the treatment of opportunistic infections. However, it is impossible to relate such colonization to a particular foodborne source, such as it is done for foodborne outbreaks: the onset of opportunistic infectious disease (e.g., urinary tract infection due to ESBL E. coli) might sporadically happen years after ingestion of the contaminated food. Thus, according to Depoorter et al. (2012), the human health risk posed by a given exposure to foodborne ESBL $E$. coli cannot be estimated yet.

In general, the situation described in Figure 1a-c applies for all foods, not only vegetables. However, the risk to encounter infection or colonization is elevated in vegetables, due to a high share of raw consumption.

Opportunistic pathogens (and apathogenic commensals) might further serve as a vehicle for the transfer of antimicrobial resistance genes (ARGs) to pathogens. This might happen in the intestine, but also before consumption as observed on lettuce with a resistance gene of clinical relevance in humans (bla $a_{\mathrm{SHV} 18}$, Jung and Matthews, 2016). DNA is partly degraded by heat, so raw consumed food is also more likely to pass high concentrations of ARGs into the human intestine.

In terms of hazard identification, additional hazard due to AMR is identified in systemic foodborne infection and in opportunistic colonization, but not in self-limiting diarrhea and intoxication.

In terms of hazard characterization, dose-response relationships are the most critical point for quantitative risk assessment. In case of obligate pathogens that would be antibiotically treated (Fig. 1a), the dose-response relationship 


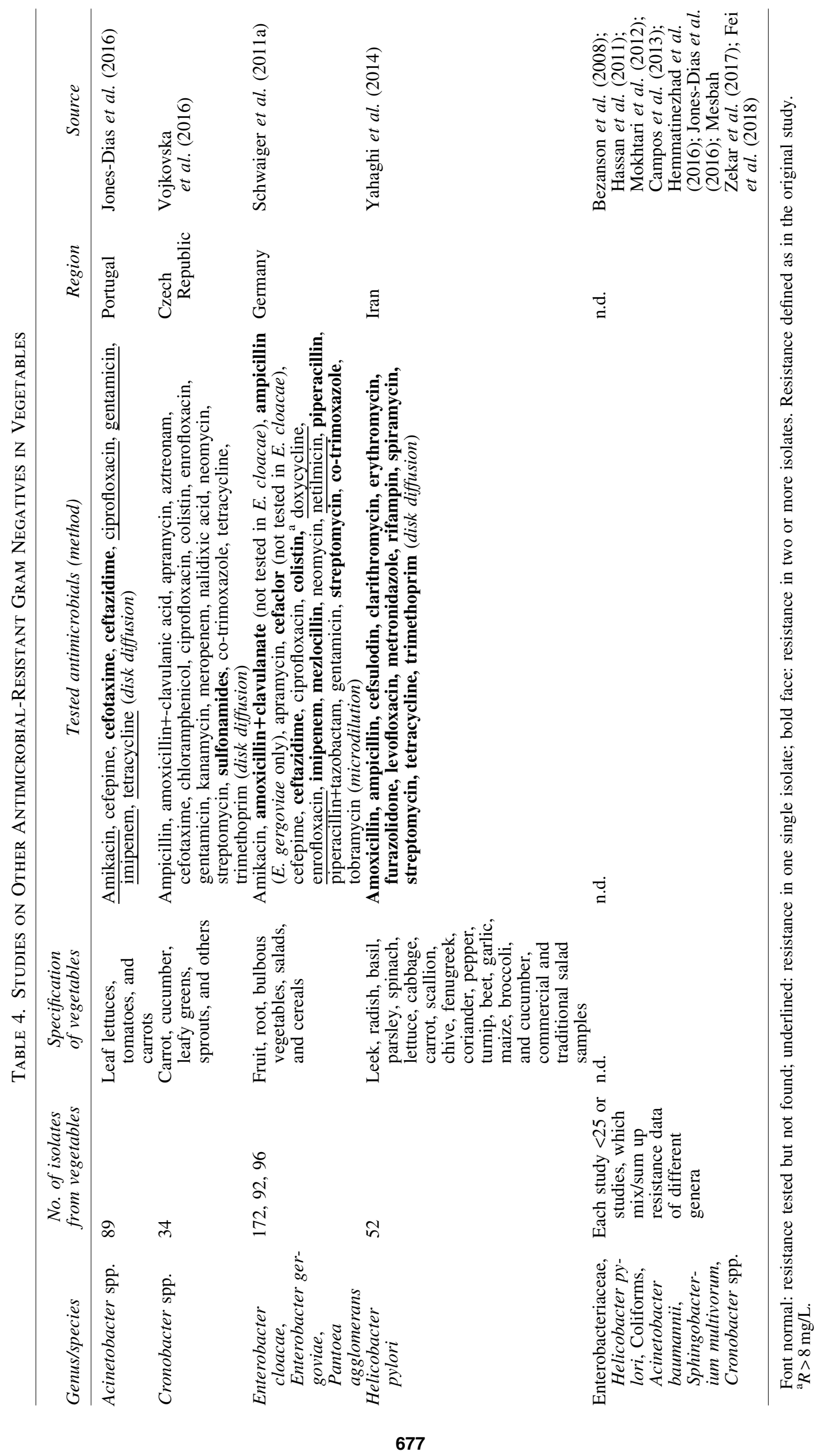




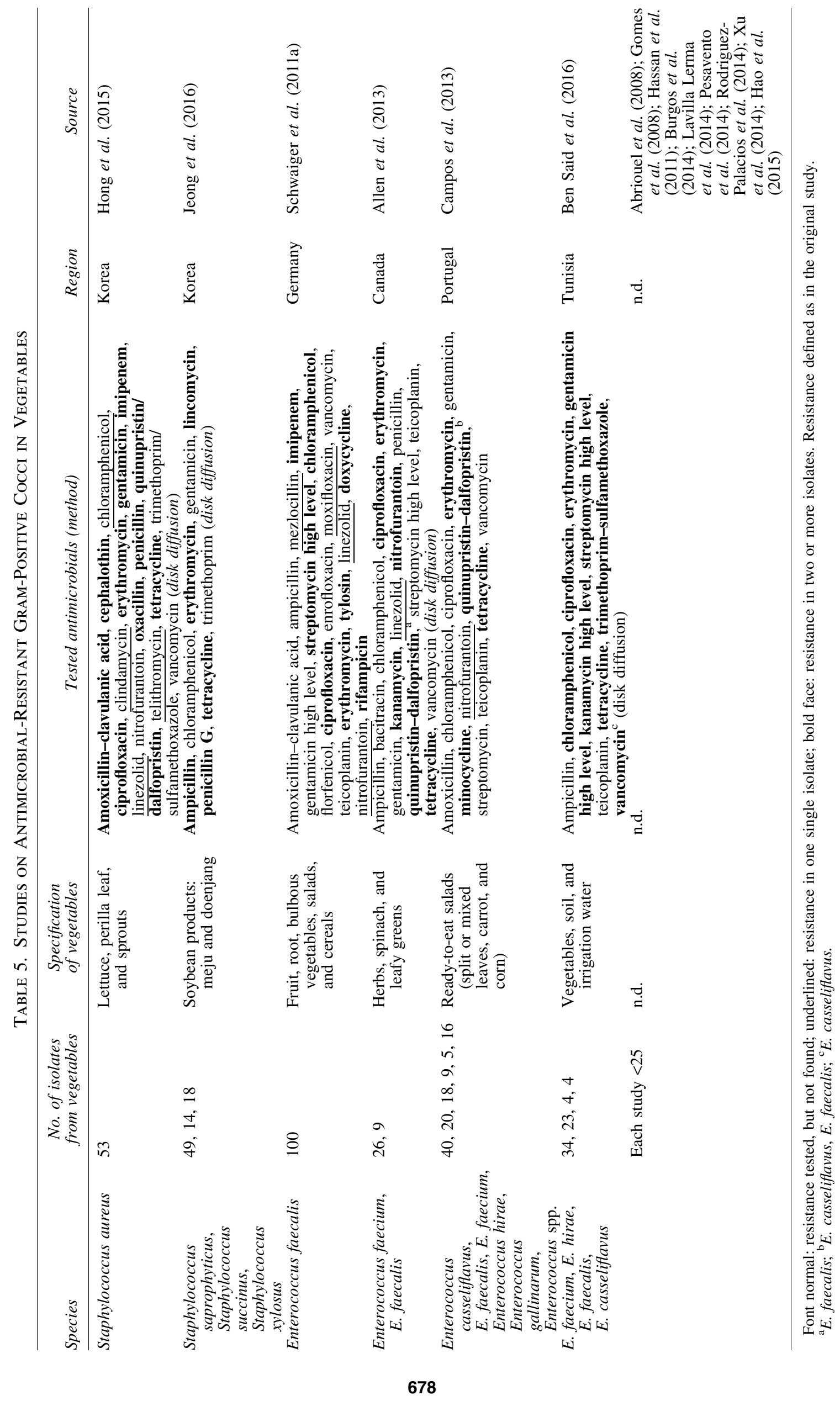



Table 6. Comparative Prevalence (\%) of Antimicrobial-Resistant Escherichia coli in Meat and Vegetables (NonSelective Approach; Calculated from Percent Positive Samples and Percent Resistant Isolates)

\begin{tabular}{lccc}
\hline Antibiotic & $\begin{array}{c}\text { Retail chicken } \\
(\mathrm{n}=250)\end{array}$ & $\begin{array}{c}\text { Retail pork } \\
(\mathrm{n}=250)\end{array}$ & $\begin{array}{c}\text { Vegetables } \\
\text { (farm+retail, } \mathrm{n}=1001)\end{array}$ \\
\hline Amoxicillin-clavulanate & $13.65^{\mathrm{a}}$ & $2.37^{\mathrm{b}}$ & $1.10^{\mathrm{b}}$ \\
Ampicillin & $34.58^{\mathrm{a}}$ & $5.90^{\mathrm{b}}$ & $1.70^{\mathrm{c}}$ \\
Piperacillin & $23.33^{\mathrm{a}}$ & $4.34^{\mathrm{b}}$ & $0.40^{\mathrm{c}}$ \\
Cefaclor & $9.30^{\mathrm{a}}$ & $2.76^{\mathrm{b}}$ & $1.90^{\mathrm{b}}$ \\
Cefoxitin & 2.40 & 0.78 & 1.30 \\
Cefuroxime & 1.95 & 0.39 & 0.80 \\
Imipenem & $1.65^{\mathrm{a}}$ & $0.00^{\mathrm{b}}$ & $0.00^{\mathrm{b}}$ \\
Gentamicin & $1.13^{\mathrm{a}}$ & $0.39^{\mathrm{a} \mathrm{b}}$ & $0.10^{\mathrm{b}}$ \\
Streptomycin & $23.63^{\mathrm{a}}$ & $7.12^{\mathrm{b}}$ & $0.30^{\mathrm{c}}$ \\
Tobramycin & 0.00 & 0.39 & 0.00 \\
Chloramphenicol & $3.60^{\mathrm{a}}$ & $1.17^{\mathrm{a}} \mathrm{b}$ & $0.50^{\mathrm{b}}$ \\
Florfenicol & 0.00 & 0.39 & 0.60 \\
Ciprofloxacin & $3.98^{\mathrm{a}}$ & $0.39^{\mathrm{b}}$ & $0.00^{\mathrm{b}}$ \\
Enrofloxacin & $4.50^{\mathrm{a}}$ & $0.39^{\mathrm{b}}$ & $0.00^{\mathrm{b}}$ \\
Colistin & 0.00 & 0.39 & 0.30 \\
Doxycycline & $30.53^{\mathrm{a}}$ & $9.46^{\mathrm{b}}$ & $0.50^{\mathrm{c}}$ \\
Sulfamethoxazole- & $31.35^{\mathrm{a}}$ & $5.51^{\mathrm{b}}$ & $0.20^{\mathrm{c}}$ \\
\hline
\end{tabular}

Different superscripts in a row: values differ significantly in a chi-squared test (Fisher's exact test, if expected values are below 5 per cell).

is that of foodborne disease, so data are available for many pathogens. In contrast, dose-response data are completely missing for stable intestinal colonization or opportunistic extraintestinal disease. For colonization, hints are provided from studies using oronasal infection to colonize animals: Schoeni and Doyle (1994) isolated E. coli O157:H7 from cecal tissue of single chickens 3 months after experimental inoculation with as low as $2.6 \times 10^{1}$ colony-forming unit (cfu).

\section{Exposure Assessment}

\section{Produce and human consumption of vegetables}

Community members of the EU produced vegetables (including melons and strawberries) on a total area of 224,126,000 ha in 2016 (http://ec.europa.eu). In Germany, more than 8000 farms produced 3,672,660 tons of vegetables for human consumption (www.destatis.de); roots, salads, and other vegetables that are commonly consumed raw constituted approximately one-third of this produce. According to EFSA data (https://dwh.efsa.europa.eu) based on 60 studies (1997-2015) from 25 countries, the mean daily consumption of vegetables and vegetable products in adults ranged from $62 \mathrm{~g}$ per capita in Sweden to $382 \mathrm{~g}$ in Romania, with excessive consumption observed in individuals (99th percentile $=1047 \mathrm{~g}$ ); these figures do not include plant products such as grains or legumes.

\section{Prevalence of $A R B$ in vegetables}

A PubMed search combining the keywords "antimicrobial resistance" or "antibiotic resistance" with "vegetables" or "fresh produce" covered the period between January 2007 and April 2018. After applying the exclusion criteria as described above, 93 hits were condensed in Tables 1-7.

The studies included bacteria of more than 20 different genera (Tables 1-7), mainly E. coli, S. enterica subsp. enterica, Listeria spp., enterococci, pseudomonads, and B. cereus. To provide basic information from the studies, resistances are marked as present or absent in Tables 1-5 (irrespective of whether they are acquired or intrinsic). Additionally, prevalences are included in Tables 6 and 7. In general, comparisons between studies should be avoided since different choices of breakpoints introduce significant bias when comparing resistance data according to the European EUCAST organization with the U.S. Clinical and Laboratory Standards Institute (CLSI). Moreover, many studies lack the information of whether they used appropriate reference strains in antimicrobial susceptibility testing.

For Salmonella, studies are hard to compare due to a high diversity in serotypes. A huge number of vegetables (more than 100,000 samples) were investigated in the United States from 2002 to 2012, resulting in isolation of 152 Salmonella strains, of which as few as 10 had detectable AMRs (Reddy et al., 2016; Table 1). However, CLSI warned that Salmonella might be falsely reported as susceptible to several antibiotics (CLSI M100-S22E, table 2A in the CLSI document) due to differences between in vitro and in vivo susceptibility. Yoke-Kqueen et al. (2008) reported 56.7\% of 134 isolates with a multiple antimicrobial resistance (MAR) index of more than 0.2. However, erythromycin was included in the MAR. Corrected for this fact, $44.3 \%$ of isolates from Malaysian vegetables were resistant to two or more antibiotics (mainly tetracycline+streptomycin-substances that are not the first- or second-line drugs in human therapy of salmonellosis). Relevant multiresistance ( $>5$ resistances, including third-generation cephalosporins) was found in Salmonella Albany, Salmonella Brunei, and Salmonella Kralingen (YokeKqueen et al., 2008).

All identified studies dealing with AMR in vegetable-borne B. cereus ( $n$ isolates $=39-110$, Table 1 ) referred to Korean fermented or traditional food (Lee et al., 2012; Kim et al., 2015; Yim et al., 2015), thus statements are restrained to a limited variety of food and regions. In addition, resistance was assessed only by means of disk diffusion, and the source and 


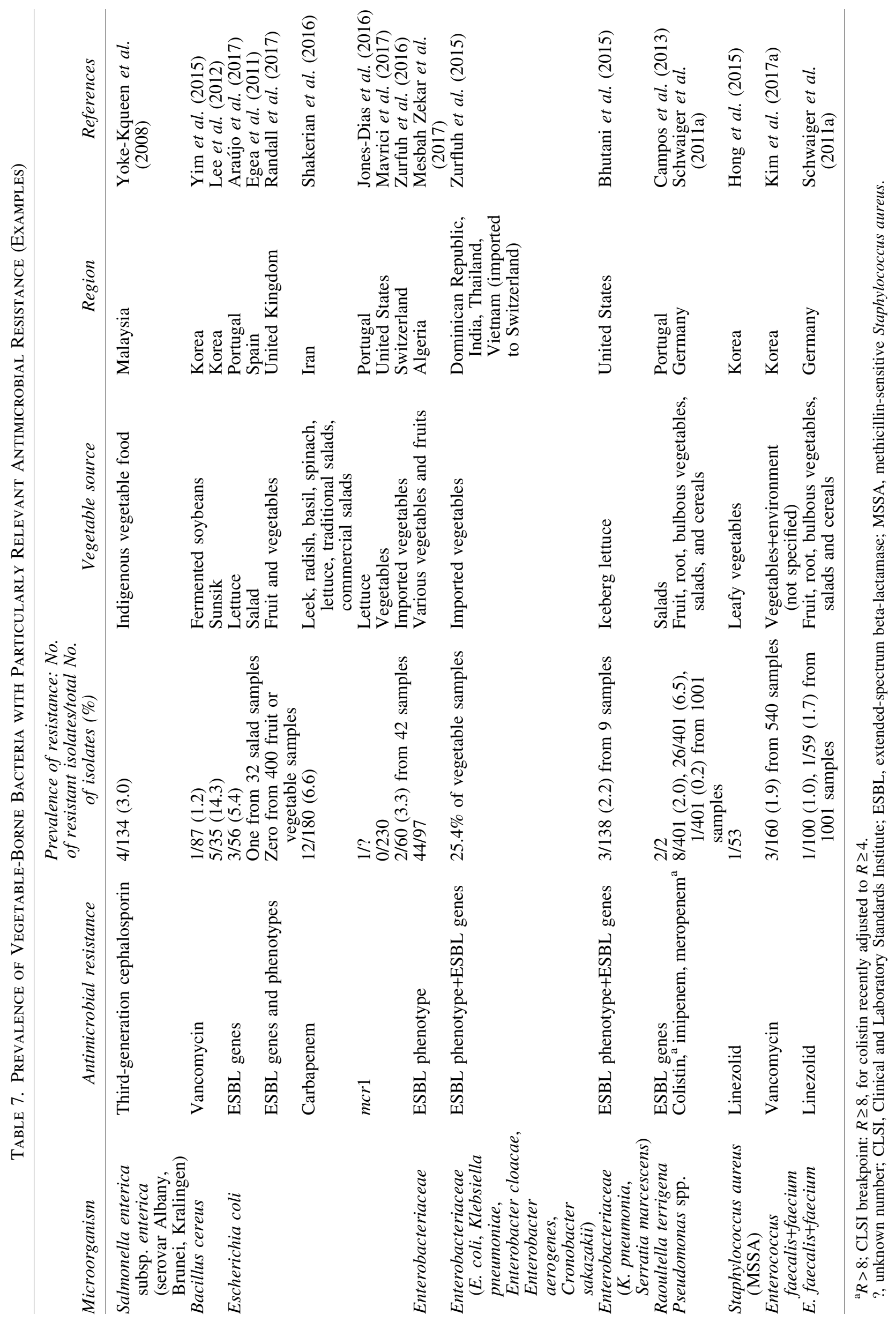




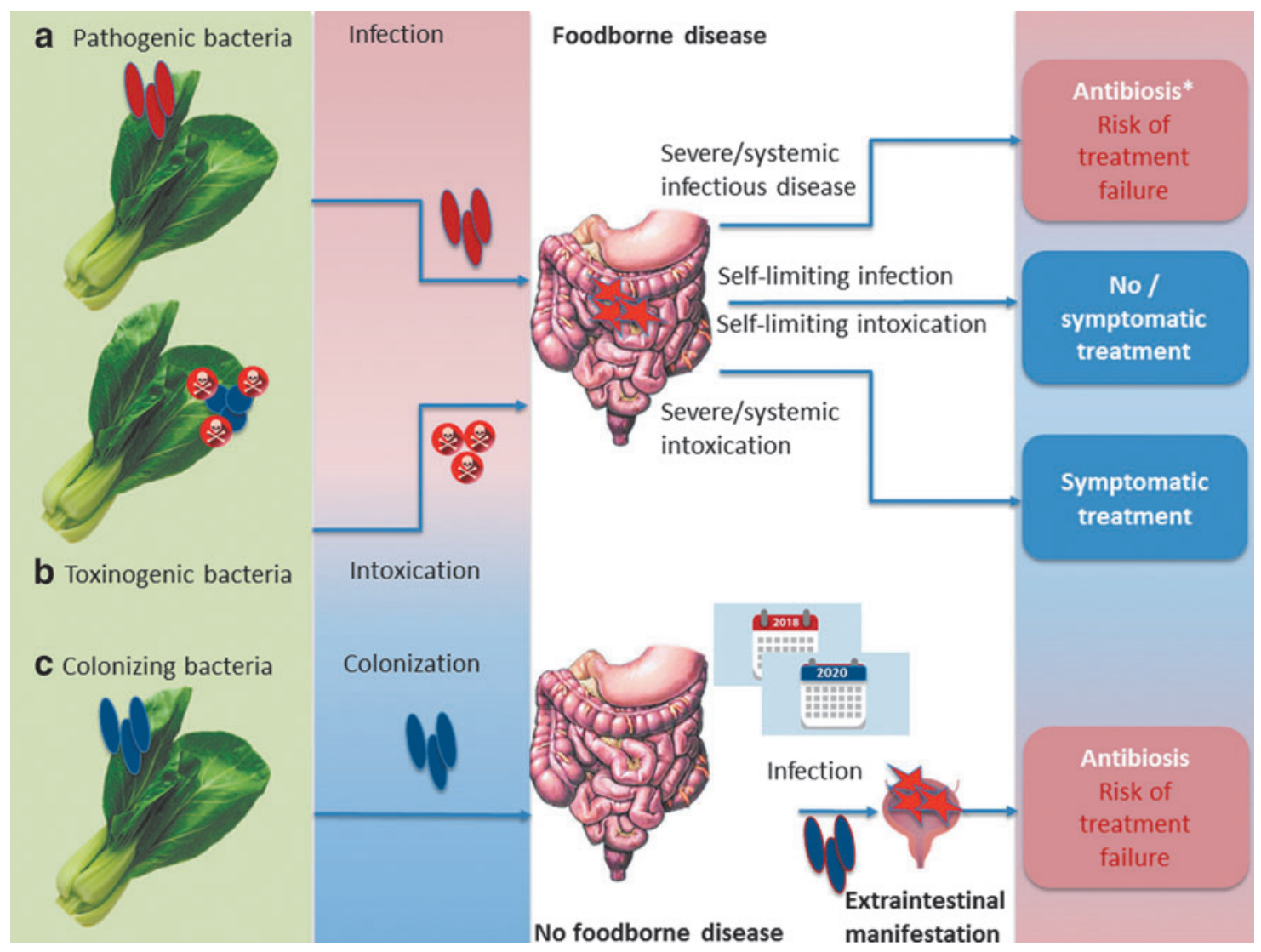

FIG. 1. Impact of antimicrobial resistance in different situations following vegetable-borne (a) infection, (b) intoxication, or (c) colonization (schematic illustration). *not for EHEC infection

validity of breakpoints is unclear, since these studies did not refer to CLSI or other acknowledged standards, but to the secondary literature. Apart from substances to which B. cereus should be considered as intrinsically resistant (e.g., ampicillin, oxacillin, penicillin, cefepime, rifampin), resistance rates were moderate, with complete susceptibility to gentamicin, imipenem, ciprofloxacin, tetracycline, and vancomycin in one study (Kim et al., 2015). However, resistance to vancomycin-a first-line therapeutic in (extraintestinal) B. cereus infectionswas reported in 1/87 isolates from fermented soybeans (Yim et al., 2015) and 5/39 isolates from Sunsik (Lee et al., 2012), a ready-to-eat food made from grains, fruits, and vegetables.

Significant data for L. monocytogenes $(n=144$, Table 1$)$ from fresh and frozen vegetables were reported from a Polish study using E-test with CLSI-breakpoints for listeria and staphylococci (Korsak et al., 2012): only one vegetable-borne isolate had detectable AMR at all (to tetracyclines). In Turkish ready-to-eat salad, listerial AMR was most pronounced to erythromycin and cephalothin (Gurler et al., 2015). However, cephalosporin resistance is considered as an intrinsic feature of L. monocytogenes (Collins et al., 2012), and erythromycin is not considered as a treatment of choice (Morvan et al., 2010).

Campylobacter jejuni $(n=33$, Table 1) from Malaysian "salad style vegetables" had moderate resistance rates except for intrinsic resistances and erythromycin resistance (60.6\%; Khalid et al., 2015). The latter fact might be remarkable since macrolides have for long been used as a therapy of choice (Blaser et al., 1979; Engberg et al., 2001).
However, the study is generally limited by the fact that breakpoints were outdated (taken from a document from 2003, when the CLSI was still named NCCLS). In any case, fluoroquinolones - a first-line therapy of today-were highly effective in this study.

Resistance data for E. coli (60-239 isolates, Table 2) differed significantly between studies; this might be related to the very different locations (South Africa, India, United States, South America, Europe, Lebanon, Iran), the different nature of samples, and the different choice of antibiotics and breakpoints.

The majority of studies reported pronounced resistance to streptomycin and tetracyclines - a finding of limited significance, given the fact that clinical breakpoints cut within natural populations. However, studies also reported significant resistance to amoxicillin combined with clavulanic acid (>15\%) (e.g., Araújo et al., 2017) or resistance to carbapenems (Shakerian et al., 2016) and third- or fourth-generation cephalosporin as well as presence of $b l a_{\mathrm{TEM}} 1$-genes (Araújo et al., 2017). Remarkably, Gómez-Aldapa et al. (2016) reported $100 \%$ resistance to amikacin and colistin in diarrheagenic $E$. coli pathotypes from Mexican cactus salads. The study referred to CLSI; however, CLSI does not provide a breakpoint for colistin in E. coli. In addition, colistin resistance was assessed by disk diffusion, a practice that is discouraged nowadays (www.eucast.org).

For pathogenic E. coli, one study assessed the prevalence of plasmid-borne colistin resistance genes $m c r 1 / m c r 2$ in STEC E. 
coli from the United States; not a single positive isolate was found in 1000 strains from different sources, including about 230 isolates from vegetables (Mavrici et al., 2017).

Due to their environmental sources, pseudomonads are frequently found in vegetables. Pseudomonads are not considered as major foodborne pathogens; however, six studies were identified, which reported resistance data of up to 401 Pseudomonas isolates from, mostly Pseudomonas aeruginosa (Table 3). Using microdilution and DIN58940-breakpoints where available, one study identified significantly higher resistance rates to aminoglycosides in Pseudomonas isolates from fruit vegetables compared with root vegetables or salads (Schwaiger et al., 2011a). In this study, resistance also included antibiotics used in clinics, such as gentamicin, tobramycin, amikacin, ciprofloxacin, colistin, piperacillin, ceftazidime, imipenem, or meropenem; however, such resistances were rare (Schwaiger et al., 2011a). Using CLSI breakpoints and disk diffusion, most of these resistances were also observed in Jamaican vegetable isolates, apart from resistance to carbapenems (Allydice-Francis and Brown, 2012).

Cronobacter spp. acts as a foodborne pathogen in immunocompromised patients (Healy et al., 2010) and will then be antibiotically treated, for example, with ampicillin plus gentamicin or chloramphenicol (Lai, 2001). However, vegetable isolates were characterized by a high rate of pansusceptible strains and lacked resistance against clinically relevant antimicrobials (Vojkovska et al., 2016; Table 4). For Enterobacter spp. $(n=264)$, several AMRs were significantly lowered at retail, compared with farm level, pointing toward a need for sampling close to consumption for particular questions of risk assessment (Schwaiger et al., 2011a; Table 4). Once more, resistance depended on the vegetable group: resistance to colistin was significantly more frequent in Enterobacter cloacae from fruit vegetables than from roots (Schwaiger et al., 2011a).

None of the studies on Gram-positive cocci (Table 5) reported staphylococci to be resistant to vancomycin, a critically important antibiotic especially for infection caused by methicillin-resistant S. aureus (MRSA). Korean leafy vegetables were partly contaminated with multiresistant MRSA strains (Hong et al., 2015). One methicillin-susceptible isolate was resistant to linezolid, a first-line drug for the treatment of MRSA-infected wounds (Gurusamy et al., 2013). Single linezolid-resistant strains of Enterococcus faecalis (1/100) and Enterococcus faecium were isolated from German vegetables (Schwaiger et al., 2011a). One linezolid-resistant E. faecium was detected in Canadian vegetables as well (Allen et al., 2013). Detectable resistance in E. faecalis isolates $(n=20)$ from Portuguese ready-to-eat salad was restrained to tetracyclines and erythromycin due to the presence of $\operatorname{tet}(\mathrm{M}), \operatorname{tet}(\mathrm{L})$, and erm(B) (Campos et al., 2013). From Tunisia, Ben Said et al. (2016) reported additional resistance to high level concentrations of aminoglycosides and chloramphenicol. By multilocus sequence typing, Leavis et al. (2006) identified vegetable-borne ARB of a so-called high-risk enterococcal clonal complex. Importantly, vancomycin-teicoplaninresistant enterococci were isolated from fresh produce or its environment in Korea (Kim et al., 2017a).

\section{Human exposure to vegetable-borne $A R B$}

Assessing the exposure of humans to vegetable-borne $\mathrm{ARB}$ is not the same as assessing the prevalence of AMR in vegetable-borne bacteria: Considerable exposure to ARB might arise in a situation when bacteria are rarely found, but frequently resistant, or vice versa in the situation when AMR is moderate, but the prevalence of bacterial contamination is very high. For Salmonella or Listeria spp., both prevalence of bacteria and prevalence of AMR within vegetable-borne bacteria are low (Reddy et al., 2016). For other bacteria such as pseudomonads, prevalence of bacteria is high, but the prevalence of clinically significant resistance is low.

Vice versa, the prevalence of E. coli or E. faecalis is much lower in vegetables than in food of animal origin, but the prevalence of AMR is remarkably high for some antibiotics and, although rare, resistances to critically important isolates are present as well. For E. coli, we had the chance to comparatively calculate the prevalence of ARB (prevalence of bacteria $\times$ prevalence of resistance) in pork, poultry, and vegetables from two studies (Schwaiger et al., 2011a, 2012 and unpublished data) using identical methods; pork and poultry were included for the sake of comparison. The studies resembled each other in identical (nonselective) bacterial isolation, identical susceptibility testing (microdilution, DIN 58940-81), and identical source of breakpoints. Results are shown in Table 6. In total, the prevalence of $E$. coli was lowest in vegetables (3.4\% compared with $75 \%$ in chicken and $25 \%$ in pork). However, for several antibiotics, the prevalence of resistant $E$. coli was quite comparable between pork and vegetables. This was because a much lower prevalence of $E$. coli in vegetables was accompanied by a high prevalence of resistance: up to $55 \%$ of the vegetable-borne $E$. coli were resistant to beta-lactams.

For quantitative risk assessment, it would be crucial to know not just the prevalence but also the concentration of ARB in vegetables since risk characterization has to consider doserelated data. However, this information is more than rare. Some of the studies listed in Tables 1-7 quantified bacteria (e.g., Hassan et al., 2011; Campos et al., 2013; Holvoet et al., 2013; Araújo et al., 2017; Du Plessis et al., 2017) but did not specifically refer to ARB. To assess these data, selective quantification for resistant bacteria would be needed, which is performed even rarer. Relevant data are provided by Ruimy et al. (2010), who reported densities of resistant bacteria as high as $10^{4} \mathrm{cfu} / \mathrm{g}$ of product for Gram negatives grown in the presence of tetracycline, chloramphenicol, and nalidixic acid. Yang et al. (2016) quantified antibiotic-resistant endophytic bacteria in experimentally grown pak choi and found concentrations of up to $9 \times 10^{2}$ per $\mathrm{g}$.

\section{Risk Characterization}

Risk characterization integrates the informations from hazard identification, hazard characterization, and exposure assessment into a quantitative estimate of risk (probability of adverse outcome or number of cases). Hazard identification related to resistant bacteria has to account for the fact whether this resistance is of therapeutic interest. This review revealed that clinically relevant antibiotics are underrepresented in current studies so that many pathogen-AMR combinations listed above do not imply any therapeutic consequence (hazard). However, ESBL production in Enterobacteriaceae or linezolid resistance in enterococci and staphylococci is surely of clinical interest.

Risk characterization would also include hazard characterization, which means dose-response relationships. Infectious 
doses vary in the individual host and situation; for many environmental bacteria, such infectious doses have not been defined at all. In addition, the amount of opportunistic pathogens or commensals, which is necessary to produce stable colonization in the human intestine, is unknown for most bacteria, and dose-response studies are absent. For foodborne outbreaks in general, case numbers are also used as a substitute in hazard characterization if dose-response data are missing. However, no specific case numbers are available for infectious disease due to vegetable-borne ARB.

In the absence of known colonization doses or known frequencies of colonization events, at least qualitative data might help to further characterize the risk. Thus, attempts were made to identify genetically related antimicrobially resistant organisms in food and human intestines or human clinical samples in a distinct region and period (e.g., Abriouel et al., 2008; Hannah et al., 2009; Burgos et al., 2014), but without showing significant association. Several studies tried to relate the presence of ARB in human feces to consumption behavior and found that vegetarians are at higher risk to carry ARB (Elder et al., 1993; Sannes et al., 2008). However, Sannes et al. (2008) also showed that this might be linked to a confounder related to the lifestyle of vegetarians: traveling abroad.

Exposure assessment identified vegetables as a relevant vehicle in terms of a high consumption frequency and in terms of frequent bacterial contamination in a ready-to-eat state. However, the exposure to clinically relevant pathogens or to commensals conferring clinically relevant resistance is low, compared with other food like meat.

Ultimately, taking together the individual steps of risk assessment, we have to state that the absence of dose-response data and the absence of published estimates on treatment failure due to AMR in foodborne infections do not allow quantitative risk characterization for vegetable-borne ARB yet.

\section{Risk Prevention: Sources of Contamination}

While sprout seeds from Egypt were considered as the most probable outbreak source for the multinational EHEC outbreak in 2011, the primary source of sprout contamination remained unknown. This is seen in most outbreaks (not only) related to vegetables, thus indirect clues are important for assessing infection chains. In rare cases, molecular typing of bacterial isolates from possible sources and contaminated vegetables is available to strengthen these indirect clues.

\section{Irrigation water as a source of $A R B$}

Worldwide, the FAO indicates a need for irrigation water as high as $1500 \mathrm{~km}^{3} /$ year; of this irrigation water, $7.38 \%$ are used for vegetables and roots (www.fao.org, data from 2012). Groundwater constitutes $38.9 \%$ of this irrigation water, the rest is taken from sources such as surface water or used water, which are more easily prone to microbial contamination than groundwater. Microbial concentrations in irrigation water are generally much lower than they are in organic fertilizers; however, filter effects of soil might concentrate microorganisms at soil surfaces, and irrigation is more continuously applied to vegetables than is organic fertilizer. Blaak et al. (2015) found that Dutch surface water contains $2.2 \times 10^{2}$ multidrug-resistant E. coli (median) and up to $6 \times 10^{2} \mathrm{ESBL}$ E. coli per microliter.
Several studies found that irrigation water and vegetables shared the same clones, as confirmed by repetitive-element polymerase chain reaction (rep-PCR: BOX-, REP-, and ERICPCR) (Jongman and Korsten, 2016; Araújo et al., 2017). Njage and Buys (2015) identified irrigation water as a possible pathway of transmission for ESBL E. coli.

\section{Soil and organic fertilizer as sources of $A R B$}

Vegetables produced in or close to soil-such as carrots and leaf vegetables - are at special risk for contamination with soil-borne bacteria, either belonging to natural soil microbiota or introduced into soil by manure fertilization. While the application of manure in ready-to-eat crops is discouraged, for example, by the U.K. Food Standards Agency (www.food.gov.uk); it is not generally prohibited by European law. In Germany, however, the use of liquid manure for top dressing is interdicted by national law; any vegetables must not be planted earlier than 12 weeks after fields had been fertilized with liquid manure.

Several studies focused on the prevalence of ARB or AMR genes in vegetables at harvest and the soil from which these vegetables were harvested (Marti et al., 2013, 2014; Wang et al., 2015; He et al., 2016; Lau et al., 2017; Tien et al., 2017); these studies found temporary-if any-impact of manuring compared with natural soil, which has a natural base level of ARG due to the presence of antimicrobialproducing microorganisms (Nesme and Simonet, 2015). Ruimy et al. (2010) showed that resistance scores were significantly higher in vegetables grown in or close to soil compared with fruits and vegetables grown above the soil. Rahube et al. $(2014,2016)$ reported that human biosolids are a relevant-but also temporary-source of ARG on vegetables at harvest, and Duan et al. (2017) found that ARG contents in soil and lettuce decreased after experimental application of biochar. Zhu et al. (2017) reported eightfold higher absolute copy numbers or ARG in manure-fertilized Chinese organic lettuce compared with conventionally produced lettuce; this difference was mainly due to different microbial communities in both types of samples. One recent study searched for ARGs in the viral DNA fraction (bacteriophages) from vegetables and soil and found that concentrations were highest for lettuce and soil, pointing toward soil as a relevant source of ARGs (Larrañaga et al., 2018).

Antibiotic residues in manure or soil might be more critical than is presence of manure-borne ARB, due to higher persistence. Antibiotic residues were able to select antimicrobially resistant endophytic bacteria, which are not removed by washing or peeling (Zhang et al., 2017; Esteban-Cuesta et al., 2018).

\section{Direct contamination by humans}

To our knowledge, systematic studies on human contamination of vegetables with ARB during production or processing are missing, as is systematic source tracking by molecular microbiological methods.

In the 2011 EHEC outbreak, it was assumed that, in a regional suboutbreak, vegetable dishes were contaminated by an infected caterer (www.rki.de). Genotyping raised suspicion that (multiresistant) $S$. aureus from Korean leafy vegetables were of human origin (Hong et al., 2015); the presence of new class 3-integrons in a pathogenic strain of Klebsiella pneumoniae was related to clinical sources by Jones-Dias 
et al. (2016). As an additional hint, we found that fruit vegetables were generally more likely to be contaminated with ARB than other vegetables; touching by consumers is discussed as a possible explanation, although not proven yet (Schwaiger et al., 2011a). A similar hypothesis was presented by Mesbah Zekar et al. (2017). Weak food hygiene standards on Nigerian farm were shown to correlate with higher bacterial loads in cut lettuce (Oyinlola et al., 2017), but these standards included only some parameters of personal hygiene besides a couple of nonhuman hygiene factors, such as surface water irrigation and manure application.

Besides the mentioned routes of contamination, other plausible ways of contamination include a broad variety of sources, either for the primary products (e.g., Salmonella contamination by reptiles and amphibians, Gorski et al., 2013) or during transport, processing, and distribution. Macrorestriction plus pulsed-field gel electrophoresis suggested that two different kinds of vegetables from two different countries were contaminated with a clonal $E$. coli strain due to packaging and distribution at the same factory. The role of processing is further illustrated by cut salads, which are generally considered as a risk food (www.fda.gov): here, processing is not only a possible source of cross-contamination but also a factor increasing water activity (thus decreasing microbial stability).

\section{Outlook: Transfer of ARB to Humans by Food of Plant Origin-Current Lacks and Future Needs for Risk Assessment}

A considerable share of studies used nonvalidated methods, reported intrinsic resistance, dealt with nonpathogenic bacteria, or provided data on AMRs/ARGs of low clinical relevance. Such limitations should be proactively addressed, if present. Commensal bacteria might be useful indicator organisms and serve as donors for AMR genes in the gut; in addition, the label pathogenic/nonpathogenic is conferred more carefully than in former since pathogenesis is more and more treated as a nonstatic interaction between strain-specific virulence and susceptibility of individual hosts. However, this fact gives even more emphasis to a need for prudent study design, overcoming the actual strategy of "count and collect" in favor of more functional approaches leading to dose-response data.

Important lacks of knowledge affect almost every part of risk assessment and management, starting from identifying sources of contamination and ending up to the black box of intestinal and infectious processes long after consumption. With regard to sources of contamination, search for plantderived ARB should include processing and distribution steps since contamination close to consumption is more likely to result in human exposure, and human contamination might be more likely to introduce strains with AMR against human therapeutics. Further research should thus focus on clinically relevant antibiotics, should provide (or reject) evidence of transmission at clonal level, and should clarify and quantify the involvement of commensals in ARG transfer to pathogens as well as in extraintestinal opportunistic infections after transmission by food. Future studies addressing these gaps would be more than welcome.

\section{Disclosure Statement}

No competing financial interests exist.

\section{References}

Abriouel H, Omar NB, Molinos AC, López RL, Grande MJ, Martínez-Viedma P, Ortega E, Cañamero MM, Galvez A. Comparative analysis of genetic diversity and incidence of virulence factors and antibiotic resistance among enterococcal populations from raw fruit and vegetable foods, water and soil, and clinical samples. Int J Food Microbiol 2008; 123:38-49.

Allen KJ, Kovacevic J, Cancarevic A, Wood J, Xu J, Gill B, Allen JK, Mesak LR. Microbiological survey of imported produce available at retail across Canada. Int J Food Microbiol 2013;162:135-142.

Allydice-Francis K, Brown PD. Diversity of antimicrobial resistance and virulence determinants in Pseudomonas aeruginosa associated with fresh vegetables. Int J Microbiol 2012; 2012:426241.

Araújo S, A T Silva I, Tacão M, Patinha C, Alves A, Henriques I. Characterization of antibiotic resistant and pathogenic Escherichia coli in irrigation water and vegetables in household farms. Int J Food Microbiol 2017;257:192-200.

Ben Said L, Klibi N, Dziri R, Borgo F, Boudabous A, Ben Slama K, Torres C. Prevalence, antimicrobial resistance and genetic lineages of Enterococcus spp. from vegetable food, soil and irrigation water in farm environments in Tunisia. J Sci Food Agric 2016;96:1627-1633.

Bergogne-Bérézin E. Treatment and prevention of antibiotic associated diarrhea. Int J Antimicrob Agents 2000;16:521526.

Bezanson GS, MacInnis R, Potter G, Hughes T. Presence and potential for horizontal transfer of antibiotic resistance in oxidase-positive bacteria populating raw salad vegetables. Int J Food Microbiol 2008;127:37-42.

Bhutani N, Muraleedharan C, Talreja D, Rana SW, Walia S, Kumar A, Walia SK. Occurrence of multidrug resistant extended spectrum beta-lactamase-producing bacteria on iceberg lettuce retailed for human consumption. Biomed Res Int 2015;2015:547547.

Blaak H, Lynch G, Italiaander R, Hamidjaja RA, Schets FM, de Roda Husman AM. Multidrug-resistant and extended spectrum beta-lactamase-producing Escherichia coli in Dutch surface water and wastewater. PLoS One 2015;10: e0127752.

Blaser MJ, Berkowitz ID, LaForce FM, Cravens J, Reller LB, Wang WL. Campylobacter enteritis: Clinical and epidemiologic features. Ann Intern Med 1979;91:179.

Borriello SP, Larson HE, Welch AR, Barclay F, Stringer MF, Bartholomew BA. Enterotoxigenic Clostridium perfringens: A possible cause of antibiotic-associated diarrhoea. Lancet 1984;1:305-307.

Buchholz U, Bernard H, Werber D, Böhmer MM, Remschmidt C, Wilking H, Deleré Y, an der Heiden M, Adlhoch C, Dreesman J, Ehlers J, Ethelberg S, Faber M, Frank C, Fricke G, Greiner M, Höhle M, Ivarsson S, Jark U, Kirchner M, Koch J, Krause G, Luber P, Rosner B, Stark K, Kühne M. German outbreak of Escherichia coli O104:H4 associated with sprouts. N Engl J Med 2011;365:1763-1770.

Burgos MJG, Aguayo MCL, Pulido RP, Gálvez A, López RL. Multilocus sequence typing and antimicrobial resistance in Enterococcus faecium isolates from fresh produce. Antonie Van Leeuwenhoek 2014;105:413-421.

Butler AJ, Thomas MK, Pintar KDM. Expert elicitation as a means to attribute 28 enteric pathogens to foodborne, waterborne, animal contact, and person-to-person transmission routes in Canada. Foodborne Pathog Dis 2015;12:335-344. 
Campos J, Mourão J, Pestana N, Peixe L, Novais C, Antunes P. Microbiological quality of ready-to-eat salads: An underestimated vehicle of bacteria and clinically relevant antibiotic resistance genes. Int J Food Microbiol 2013;166:464-470.

[CLSI] Clinical and Laboratory Standards Institute. Performance Standards for Antimicrobial Susceptibility Testing; Twenty-Second Informational Supplement. CLSI document M100-S22. Wayne, PA: Clinical and Laboratory Standards Institute, 2012.

Chen M, Wu Q, Zhang J, Wu S, Guo W. Prevalence, enumeration, and pheno- and genotypic characteristics of Listeria monocytogenes isolated from raw foods in South China. Front Microbiol 2015;6:1026.

Collins B, Guinane CM, Cotter PD, Hill C, Ross RP. Assessing the contributions of the LiaS histidine kinase to the innate resistance of Listeria monocytogenes to nisin, cephalosporins, and disinfectants. Appl Environ Microbiol 2012;78:29232929.

Danyluk MD, Schaffner DW. Quantitative assessment of the microbial risk of leafy greens from farm to consumption: Preliminary framework, data, and risk estimates. J Food Prot 2011;74:700-708.

Darmon N, Darmon M, Maillot M, Drewnowski A. A nutrient density standard for vegetables and fruits: Nutrients per calorie and nutrients per unit cost. J Am Diet Assoc 2005;105: 1881-1887.

Depoorter P, Persoons D, Uyttendaele M, Butaye P, de Zutter L, Dierick K, Herman L, Imberechts H, van Huffel X, Dewulf J. Assessment of human exposure to 3rd generation cephalosporin resistant E. coli (CREC) through consumption of broiler meat in Belgium. Int J Food Microbiol 2012;159:30-38.

Du Plessis EM, Govender S, Pillay B, Korsten L. Exploratory study into the microbiological quality of spinach and cabbage purchased from street vendors and retailers in Johannesburg, South Africa. J Food Prot 2017;80:1726-1733.

Duan M, Li H, Gu J, Tuo X, Sun W, Qian X, Wang X. Effects of biochar on reducing the abundance of oxytetracycline, antibiotic resistance genes, and human pathogenic bacteria in soil and lettuce. Environ Pollut 2017;224:787-795.

EFSA. Technical specifications on the harmonised monitoring and reporting of antimicrobial resistance in Salmonella, Campylobacter and indicator Escherichia coli and Enterococcus spp. bacteria transmitted through food. EFSA J 2012;10:311.

EFSA. Risks for public health related to the presence of $B a$ cillus cereus and other Bacillus spp. including Bacillus thuringiensis in foodstuffs. EFSA J 2016;14:122.

Egea P, López-Cerero L, Navarro MD, Rodríguez-Baño J, Pascual A. Assessment of the presence of extended-spectrum beta-lactamase-producing Escherichia coli in eggshells and ready-to-eat products. Eur J Clin Microbiol Infect Dis 2011; 30:1045-1047.

Ehling-Schulz M, Svensson B, Guinebretiere M-H, Lindbäck T, Andersson M, Schulz A, Fricker M, Christiansson A, Granum PE, Märtlbauer E, Nguyen-The C, Salkinoja-Salonen M, Scherer S. Emetic toxin formation of Bacillus cereus is restricted to a single evolutionary lineage of closely related strains. Microbiology 2005;151(Pt 1):183-197.

Elder HA, Roy I, Lehman S, Phillips RL, Kass EH. Human studies to measure the effect of antibiotic residues. Vet Hum Toxicol 1993;35(Suppl 1):31-36.

Engberg J, Aarestrup FM, Taylor DE, Gerner-Smidt P, Nachamkin I. Quinolone and macrolide resistance in Campylobacter jejuni and C. coli: Resistance mechanisms and trends in human isolates. Emerg Infect Dis 2001;7:24-34.
Esteban-Cuesta I, Drees N, Ulrich S, Stauch P, Sperner B, Schwaiger K, Gareis M, Gottschalk C. Endogenous microbial contamination of melons (Cucumis melo) from international trade: An underestimated risk for the consumer? J Sci Food Agric 2018;98:5074-5081.

Estepa V, Rojo-Bezares B, Torres C, Sáenz Y. Genetic lineages and antimicrobial resistance in Pseudomonas spp. isolates recovered from food samples. Foodborne Pathog Dis 2015; 12:486-491.

Faour-Klingbeil D, Kuri V, Fadlallah S, Matar GM. Prevalence of antimicrobial-resistant Escherichia coli from raw vegetables in Lebanon. J Infect Dev Ctries 2016;10:354-362.

Fei P, Jiang Y, Gong S, Li R, Jiang Y, Yuan X, Wang Z, Kang H, Ali MA. Occurrence, genotyping, and antibiotic susceptibility of Cronobacter spp. in drinking water and food samples from Northeast China. J Food Prot 2018:456-460.

Franklin A, Acar J, Anthony F, Gupta R, Nicholls T, Tamura Y, Thompson S, Threlfall EJ, Vose D, van Vuuren M, White DG, Wegener HC, Costarrica ML. Antimicrobial resistance: Harmonisation of national antimicrobial resistance monitoring and surveillance programmes in animals and in animalderived food. Rev Sci Tech 2001;20:859-870.

Franz E, Tromp SO, Rijgersberg H, Van Der Fels-Klerx HJ. Quantitative microbial risk assessment for Escherichia coli O157:H7, Salmonella, and Listeria monocytogenes in leafy green vegetables consumed at salad bars. J Food Prot 2010; 73:274-285.

Goldwater PN, Bettelheim KA. Treatment of enterohemorrhagic Escherichia coli (EHEC) infection and hemolytic uremic syndrome (HUS). BMC Med 2012;10:12.

Gomes BC, Esteves CT, Palazzo ICV, Darini ALC, Felis GE, Sechi LA, Franco BDGM, de Martinis ECP. Prevalence and characterization of Enterococcus spp. isolated from Brazilian foods. Food Microbiol 2008;25:668-675.

Gómez-Aldapa CA, Cerna-Cortes JF, Rangel-Vargas E, TorresVitela MR, Villarruel-López A, Gutiérrez-Alcántara EJ, Castro-Rosas J. Presence of multidrug-resistant Shiga toxinproducing Escherichia coli, enteropathogenic E. coli and enterotoxigenic $E$. coli, on raw nopalitos (Opuntia ficusindica L.) and in nopalitos salads from local retail markets in Mexico. Foodborne Pathog Dis 2016;13:269-274.

Gorski L, Jay-Russell MT, Liang AS, Walker S, Bengson Y, Govoni J, Mandrell RE. Diversity of pulsed-field gel electrophoresis pulsotypes, serovars, and antibiotic resistance among Salmonella isolates from wild amphibians and reptiles in the California Central Coast. Foodborne Pathog Dis 2013; 10:540-548.

Grif K, Dierich MP, Karch H, Allerberger F. Strain-specific differences in the amount of Shiga toxin released from enterohemorrhagic Escherichia coli $\mathrm{O} 157$ following exposure to subinhibitory concentrations of antimicrobial agents. Eur J Clin Microbiol Infect Dis 1998;17:761-766.

Guchi B, Ashenafi M. Microbial load, prevalence and antibiograms of Salmonella and Shigella in lettuce and green peppers. Ethiop J Health Sci 2010;20:41-48.

Guerrant RL, van Gilder T, Steiner TS, Thielman NM, Slutsker L, Tauxe RV, Hennessy T, Griffin PM, DuPont H, Sack RB, Tarr P, Neill M, Nachamkin I, Reller LB, Osterholm MT, Bennish ML, Pickering LK. Practice guidelines for the management of infectious diarrhea. Clin Infect Dis 2001;32:331-351.

Gurler Z, Pamuk S, Yildirim Y, Ertas N. The microbiological quality of ready-to-eat salads in Turkey: A focus on Salmonella spp. and Listeria monocytogenes. Int J Food Microbiol 2015; 196:79-83. 
Gurusamy KS, Koti R, Toon CD, Wilson P, Davidson BR. Antibiotic therapy for the treatment of methicillin-resistant Staphylococcus aureus (MRSA) infections in surgical wounds. Cochrane Database Syst Rev 2013;(8):CD009726.

Hamilton AJ, Stagnitti F, Premier R, Boland A-M, Hale G. Quantitative microbial risk assessment models for consumption of raw vegetables irrigated with reclaimed water. Appl Environ Microbiol 2006;72:3284-3290.

Hannah EL, Johnson JR, Angulo F, Haddadin B, Williamson J, Samore MH. Molecular analysis of antimicrobial-susceptible and -resistant Escherichia coli from retail meats and human stool and clinical specimens in a rural community setting. Foodborne Pathog Dis 2009;6:285-295.

Hao D, Xing X, Li G, Wang X, Zhang M, Zhang W, Xia X, Meng J. Prevalence, toxin gene profiles, and antimicrobial resistance of Staphylococcus aureus isolated from quickfrozen dumplings. J Food Prot 2015;78:218-223.

Hassan SA, Altalhi AD, Gherbawy YA, El-Deeb BA. Bacterial load of fresh vegetables and their resistance to the currently used antibiotics in Saudi Arabia. Foodborne Pathog Dis 2011; 8:1011-1018.

He LY, Ying GG, Liu YS, Su HC, Chen J, Liu SS, Zhao JL. Discharge of swine wastes risks water quality and food safety: Antibiotics and antibiotic resistance genes from swine sources to the receiving environments. Environ Int 2016;9293:210-219.

Healy B, Cooney S, O'Brien S, Iversen C, Whyte P, Nally J, Callanan JJ, Fanning S. Cronobacter (Enterobacter sakazakii): An opportunistic foodborne pathogen. Foodborne Pathog Dis 2010;7:339-350.

Hemmatinezhad B, Momtaz H, Rahimi E. VacA, cagA, iceA and oipA genotypes status and antimicrobial resistance properties of Helicobacter pylori isolated from various types of ready to eat foods. Ann Clin Microbiol Antimicrob 2016; $15: 2$.

Holvoet K, Sampers I, Callens B, Dewulf J, Uyttendaele M. Moderate prevalence of antimicrobial resistance in Escherichia coli isolates from lettuce, irrigation water, and soil. Appl Environ Microbiol 2013;79:6677-6683.

Hong J, Kim Y, Kim J, Heu S, Kim S-R, Kim K-P, Roh E. Genetic diversity and antibiotic resistance patterns of Staphylococcus aureus isolated from leaf vegetables in Korea. J Food Sci 2015;80:M1526-M1531.

Jeong D-W, Lee B, Her J-Y, Lee K-G, Lee J-H. Safety and technological characterization of coagulase-negative staphylococci isolates from traditional Korean fermented soybean foods for starter development. Int J Food Microbiol 2016; 236:9-16.

Jones-Dias D, Manageiro V, Ferreira E, Barreiro P, Vieira L, Moura IB, Caniça M. Architecture of class 1, 2, and 3 integrons from gram negative bacteria recovered among fruits and vegetables. Front Microbiol 2016;7:1400.

Jongman M, Korsten L. Genetic diversity and antibiotic resistance of Escherichia coli isolates from different leafy green production systems. J Food Prot 2016;79:1846-1853.

Jung Y, Matthews KR. Potential transfer of extended spectrum $\beta$-lactamase encoding gene, blashv18 gene, between Klebsiella pneumoniae in raw foods. Food Microbiol 2016;60: 39-48.

Kadariya J, Smith TC, Thapaliya D. Staphylococcus aureus and staphylococcal food-borne disease: An ongoing challenge in public health. Biomed Res Int 2014;2014:827965.

Khalid MI, Tang JYH, Baharuddin NH, Rahman NS, Rahimi NF, Radu S. Prevalence, antibiogram, and cdt genes of toxigenic
Campylobacter jejuni in salad style vegetables (ulam) at farms and retail outlets in Terengganu. J Food Prot 2015;78:65-71.

Kim C-W, Cho S-H, Kang S-H, Park Y-B, Yoon M-H, Lee J-B, No W-S, Kim J-B. Prevalence, genetic diversity, and antibiotic resistance of Bacillus cereus isolated from Korean fermented soybean products. J Food Sci 2015;80:M123-M128.

Kim M-C, Cha M-H, Ryu J-G, Woo G-J. Characterization of vancomycin-resistant Enterococcus faecalis and Enterococcus faecium isolated from fresh produces and human fecal samples. Foodborne Pathog Dis 2017a;14:195-201.

Kim S, Woo G-J. Prevalence and characterization of antimicrobialresistant Escherichia coli isolated from conventional and organic vegetables. Foodborne Pathog Dis 2014;11:815-821.

Kim YJ, Kim SH, Ahn J, Cho S, Kim D, Kim K, Lee H, Son H, Lee HJ, Yong D, Choi JY, Kim HR, Shin JH. Prevalence of Clostridium perfringens toxin in patients suspected of having antibiotic-associated diarrhea. Anaerobe 2017b;48:34-36.

Korsak D, Borek A, Daniluk S, Grabowska A, Pappelbaum K. Antimicrobial susceptibilities of Listeria monocytogenes strains isolated from food and food processing environment in Poland. Int J Food Microbiol 2012;158:203-208.

Lai KK. Enterobacter sakazakii infections among neonates, infants, children, and adults. Case reports and a review of the literature. Medicine 2001;80:113-122.

Larrañaga O, Brown-Jaque M, Quirós P, Gómez-Gómez C, Blanch AR, Rodríguez-Rubio L, Muniesa M. Phage particles harboring antibiotic resistance genes in fresh-cut vegetables and agricultural soil. Environ Int 2018;115:133-141.

Lau CH-F, Li B, Zhang T, Tien Y-C, Scott A, Murray R, Sabourin L, Lapen DR, Duenk P, Topp E. Impact of preapplication treatment on municipal sludge composition, soil dynamics of antibiotic resistance genes, and abundance of antibiotic-resistance genes on vegetables at harvest. Sci Total Environ 2017;587-588:214-222.

Lavilla Lerma L, Benomar N, Valenzuela AS, Casado Muñoz Mdel C, Gálvez A, Abriouel H. Role of EfrAB efflux pump in biocide tolerance and antibiotic resistance of Enterococcus faecalis and Enterococcus faecium isolated from traditional fermented foods and the effect of EDTA as EfrAB inhibitor. Food Microbiol 2014;44:249-257.

Leavis HL, Bonten MJM, Willems RJL. Identification of highrisk enterococcal clonal complexes: Global dispersion and antibiotic resistance. Curr Opin Microbiol 2006;9:454-460.

Lee N, Sun JM, Kwon KY, Kim HJ, Koo M, Chun HS. Genetic diversity, antimicrobial resistance, and toxigenic profiles of Bacillus cereus strains isolated from Sunsik. J Food Prot 2012;75:225-230.

Lee W-J, Kim H-B, Kim K-S. Isolation and characterization of spore-forming bacilli (SFB) from Shepherd's Purse (Capsella bursa-pastoris). J Food Sci 2016;81:M684-M691.

Lima CM, Souza IEGL, Dos Santos Alves T, Leite CC, Evangelista-Barreto NS, de Castro Almeida RC. Antimicrobial resistance in diarrheagenic Escherichia coli from ready-to-eat foods. J Food Sci Technol 2017;54:3612-3619.

Liu S, Kilonzo-Nthenge A. Prevalence of multidrug-resistant bacteria from U.S.-grown and imported fresh produce retailed in chain supermarkets and ethnic stores of Davidson County, Tennessee. J Food Prot 2017;80:506-514.

Mąka Ł, Maćkiw E, Ścieżyńska H, Popowska M. Occurrence and antimicrobial resistance of Salmonella spp. isolated from food other than meat in Poland. Ann Agric Environ Med 2015;22:403-408.

Marti R, Scott A, Tien Y-C, Murray R, Sabourin L, Zhang Y, Topp E. Impact of manure fertilization on the abundance of 
antibiotic-resistant bacteria and frequency of detection of antibiotic resistance genes in soil and on vegetables at harvest. Appl Environ Microbiol 2013;79:5701-5709.

Marti R, Tien YC, Murray R, Scott A, Sabourin L, Topp E. Safely coupling livestock and crop production systems: How rapidly do antibiotic resistance genes dissipate in soil following a commercial application of swine or dairy manure? Appl Environ Microbiol 2014;80:3258-3265.

Mavrici D, Yambao JC, Lee BG, Quiñones B, He X. Screening for the presence of $m c r-1 / m c r-2$ genes in Shiga toxin-producing Escherichia coli recovered from a major produceproduction region in California. PLoS One 2017;12:e187827.

Mellmann A, Harmsen D, Cummings CA, Zentz EB, Leopold SR, Rico A, Prior K, Szczepanowski R, Ji Y, Zhang W, McLaughlin SF, Henkhaus JK, Leopold B, Bielaszewska M, Prager R, Brzoska PM, Moore RL, Guenther S, Rothberg JM, Karch H. Prospective genomic characterization of the German enterohemorrhagic Escherichia coli O104:H4 outbreak by rapid next generation sequencing technology. PLoS One 2011;6:e22751.

Mesbah Zekar F, Granier SA, Marault M, Yaici L, Gassilloud B, Manceau C, Touati A, Millemann Y. From farms to markets: Gram-negative bacteria resistant to third-generation cephalosporins in fruits and vegetables in a region of North Africa. Front Microbiol 2017;8:1569.

Miranda JM, Mondragón AC, Martinez B, Guarddon M, Rodriguez JA. Prevalence and antimicrobial resistance patterns of Salmonella from different raw foods in Mexico. J Food Prot 2009;72:966-971.

Mokhtari W, Nsaibia S, Majouri D, Ben Hassen A, Gharbi A, Aouni M. Detection and characterization of Shigella species isolated from food and human stool samples in Nabeul, Tunisia, by molecular methods and culture techniques. J Appl Microbiol 2012;113:209-222.

Morvan A, Moubareck C, Leclercq A, Hervé-Bazin M, Bremont S, Lecuit M, Courvalin P, Le Monnier A. Antimicrobial resistance of Listeria monocytogenes strains isolated from humans in France. Antimicrob Agents Chemother 2010;54: $2728-2731$.

Nesme J, Simonet P. The soil resistome: A critical review on antibiotic resistance origins, ecology and dissemination potential in telluric bacteria. Environ Microbiol 2015;17:913-930.

Niyomdecha N, Mungkornkaew N, Samosornsuk W. Serotypes and antimicrobial resistance of Salmonella enterica isolated from pork, chicken meat and lettuce, Bangkok and Central Thailand. Southeast Asian J Trop Med Public Health 2016; 47:31-39.

Njage PMK, Buys EM. Pathogenic and commensal Escherichia coli from irrigation water show potential in transmission of extended spectrum and AmpC $\beta$-lactamases determinants to isolates from lettuce. Microb Biotechnol 2015;8:462-473.

Oyinlola LA, Obadina AO, Omemu AM, Oyewole OB. Prevention of microbial hazard on fresh-cut lettuce through adoption of food safety and hygienic practices by lettuce farmers. Food Sci Nutr 2017;5:67-75.

Pang H, Lambertini E, Buchanan RL, Schaffner DW, Pradhan AK. Quantitative microbial risk assessment for Escherichia coli O157:H7 in fresh-cut lettuce. J Food Prot 2017;80:302-311.

Pesavento G, Calonico C, Ducci B, Magnanini A, Lo Nostro A. Prevalence and antibiotic resistance of Enterococcus spp. isolated from retail cheese, ready-to-eat salads, ham, and raw meat. Food Microbiol 2014;41:1-7.

Rahube TO, Marti R, Scott A, Tien YC, Murray R, Sabourin L, Duenk P, Lapen DR, Topp E. Persistence of antibiotic re- sistance and plasmid-associated genes in soil following application of sewage sludge and abundance on vegetables at harvest. Can J Microbiol 2016;62:600-607.

Rahube TO, Marti R, Scott A, Tien YC, Murray R, Sabourin L, Zhang Y, Duenk P, Lapen DR, Topp E. Impact of fertilizing with raw or anaerobically digested sewage sludge on the abundance of antibiotic-resistant coliforms, antibiotic resistance genes, and pathogenic bacteria in soil and on vegetables at harvest. Appl Environ Microbiol 2014;80:6898-6907.

Randall LP, Lodge MP, Elviss NC, Lemma FL, Hopkins KL, Teale CJ, Woodford N. Evaluation of meat, fruit and vegetables from retail stores in five United Kingdom regions as sources of extended-spectrum beta-lactamase (ESBL)-producing and carbapenem-resistant Escherichia coli. Int J Food Microbiol 2017;241:283-290.

Rasheed MU, Thajuddin N, Ahamed P, Teklemariam Z, Jamil K. Antimicrobial drug resistance in strains of Escherichia coli isolated from food sources. Rev Inst Med Trop Sao Paulo 2014;56:341-346.

Raufu I, Bortolaia V, Svendsen CA, Ameh JA, Ambali AG, Aarestrup FM, Hendriksen RS. The first attempt of an active integrated laboratory-based Salmonella surveillance programme in the north-eastern region of Nigeria. J Appl Microbiol 2013;115:1059-1067.

Reddy SP, Wang H, Adams JK, Feng PCH. Prevalence and characteristics of Salmonella serotypes isolated from fresh produce marketed in the United States. J Food Prot 2016;79: 6-16.

Rodriguez-Palacios A, Ilic S, LeJeune JT. Clostridium difficile with moxifloxacin/clindamycin resistance in vegetables in Ohio, USA, and prevalence meta-analysis. J Pathog 2014; 2014:158601.

Rosenquist H, Smidt L, Andersen SR, Jensen GB, Wilcks A. Occurrence and significance of Bacillus cereus and Bacillus thuringiensis in ready-to-eat food. FEMS Microbiol Lett 2005;250:129-136.

Ruimy R, Brisabois A, Bernede C, Skurnik D, Barnat S, Arlet G, Momcilovic S, Elbaz S, Moury F, Vibet M-A, Courvalin P, Guillemot D, Andremont A. Organic and conventional fruits and vegetables contain equivalent counts of gram-negative bacteria expressing resistance to antibacterial agents. Environ Microbiol 2010;12:608-615.

Safdar A, Armstrong D. Antimicrobial activities against 84 Listeria monocytogenes isolates from patients with systemic listeriosis at a comprehensive cancer center (1955-1997). J Clin Microbiol 2003;41:483-485.

Sannes MR, Belongia EA, Kieke B, Smith K, Kieke A, Vandermause M, Bender J, Clabots C, Winokur P, Johnson JR. Predictors of antimicrobial-resistant Escherichia coli in the feces of vegetarians and newly hospitalized adults in Minnesota and Wisconsin. J Infect Dis 2008;197:430-434.

Schoeni JL, Doyle MP. Variable colonization of chickens perorally inoculated with Escherichia coli O157:H7 and subsequent contamination of eggs. Appl Environ Microbiol 1994; 60:2958-2962.

Schwaiger K, Helmke K, Hölzel CS, Bauer J. Antibiotic resistance in bacteria isolated from vegetables with regards to the marketing stage (farm vs. supermarket). Int J Food Microbiol 2011a;148:191-196.

Schwaiger K, Hölzel C, Bauer J. Detection of the macrolideefflux protein A gene mef(A) in Enterococcus faecalis. Microb Drug Resist 2011b;17:429-432.

Schwaiger K, Huther S, Hölzel C, Kämpf P, Bauer J. Prevalence of antibiotic-resistant Enterobacteriaceae isolated 
from chicken and pork meat purchased at the slaughterhouse and at retail in Bavaria, Germany. Int J Food Microbiol 2012; 154:206-211.

Shakerian A, Rahimi E, Emad P. Vegetables and restaurant salads as a reservoir for Shiga toxigenic Escherichia coli: Distribution of virulence factors, O-serogroups, and antibiotic resistance properties. J Food Prot 2016;79:1154-1160.

Singh BR, Singh P, Agrawal S, Teotia U, Verma A, Sharma S, Chandra M, Babu N, Kant Agarwal R. Prevalence of multidrug resistant Salmonella in coriander, mint, carrot, and radish in Bareilly and Kanpur, northern India. Foodborne Pathog Dis 2007;4:233-240.

Skočková A, Karpíšková R, Koláčková I, Cupáková Š. Characteristics of Escherichia coli from raw vegetables at a retail market in the Czech Republic. Int J Food Microbiol 2013; 167:196-201.

Smith KE, Wilker PR, Reiter PL, Hedican EB, Bender JB, Hedberg CW. Antibiotic treatment of Escherichia coli $\mathrm{O} 157$ infection and the risk of hemolytic uremic syndrome, Minnesota. Pediatr Infect Dis J 2012;31:37-41.

Spiliopoulou A, Papachristou E, Foka A, Kolonitsiou F, Anastassiou ED, Goumenos DS, Spiliopoulou I. Relapsing Bacillus cereus peritonitis in a patient treated with continuous ambulatory peritoneal dialysis. JMM Case Rep 2014;1:e003400.

Taban BM, Aytac SA, Akkoc N, Akcelik M. Characterization of antibiotic resistance in Salmonella enterica isolates determined from ready-to-eat (RTE) salad vegetables. Braz J Microbiol 2013;44:385-391.

Tarr PI, Gordon CA, Chandler WL. Shiga-toxin-producing Escherichia coli and haemolytic uraemic syndrome. Lancet 2005;365:1073-1086.

Tien Y-C, Li B, Zhang T, Scott A, Murray R, Sabourin L, Marti $\mathrm{R}$, Topp E. Impact of dairy manure pre-application treatment on manure composition, soil dynamics of antibiotic resistance genes, and abundance of antibiotic-resistance genes on vegetables at harvest. Sci Total Environ 2017;581-582:32-39.

Uzal FA, Freedman JC, Shrestha A, Theoret JR, Garcia J, Awad MM, Adams V, Moore RJ, Rood JI, McClane BA. Towards an understanding of the role of Clostridium perfringens toxins in human and animal disease. Future Microbiol 2014;9:361-377.

van de Sande-Bruinsma N, Leverstein van Hall MA, Janssen M, Nagtzaam N, Leenders S, Greeff SC de, Schneeberger PM. Impact of livestock-associated MRSA in a hospital setting. Antimicrob Resist Infect Control 2015;4:11.

de Vasconcelos Byrne V, Hofer E, Vallim DC, de Castro Almeida RC. Occurrence and antimicrobial resistance patterns of Listeria monocytogenes isolated from vegetables. Braz J Microbiol 2016;47:438-443.

Verma P, Saharan VV, Nimesh S, Singh AP. Phenotypic and virulence traits of Escherichia coli and Salmonella strains isolated from vegetables and fruits from India. J Appl Microbiol 2018;125:270-281.

Vojkovska H, Karpiskova R, Orieskova M, Drahovska H. Characterization of Cronobacter spp. isolated from food of plant origin and environmental samples collected from farms and from supermarkets in the Czech Republic. Int J Food Microbiol 2016;217:130-136.

Wang F-H, Qiao M, Chen Z, Su J-Q, Zhu Y-G. Antibiotic resistance genes in manure-amended soil and vegetables at harvest. J Hazard Mater 2015;299:215-221.

Wang L, Nakamura H, Kage-Nakadai E, Hara-Kudo Y, Nishikawa Y. Prevalence, antimicrobial resistance and multiplelocus variable-number tandem-repeat analysis profiles of diarrheagenic Escherichia coli isolated from different retail foods. Int J Food Microbiol 2017;249:44-52.

Xu J, Shi C, Song M, Xu X, Yang P, Paoli G, Shi X. Phenotypic and genotypic antimicrobial resistance traits of foodborne Staphylococcus aureus isolates from Shanghai. J Food Sci 2014;79:M635-M642.

Yahaghi E, Khamesipour F, Mashayekhi F, Safarpoor Dehkordi F, Sakhaei MH, Masoudimanesh M, Khameneie MK. Helicobacter pylori in vegetables and salads: Genotyping and antimicrobial resistance properties. Biomed Res Int 2014; 2014:757941.

Yan H, Neogi SB, Mo Z, Guan W, Shen Z, Zhang S, Li L, Yamasaki S, Shi L, Zhong N. Prevalence and characterization of antimicrobial resistance of foodborne Listeria monocytogenes isolates in Hebei province of Northern China, 2005-2007. Int J Food Microbiol 2010;144:310-316.

Yang Q, Zhang H, Guo Y, Tian T. Influence of chicken manure fertilization on antibiotic-resistant bacteria in soil and the endophytic bacteria of Pakchoi. Int $\mathbf{J}$ Environ Res Public Health 2016;13:662.

Yim J-H, Kim K-Y, Chon J-W, Kim D-H, Kim H-S, Choi D-S, Choi I-S, Seo K-H. Incidence, antibiotic susceptibility, and toxin profiles of Bacillus cereus sensu lato isolated from Korean fermented soybean products. J Food Sci 2015;80: M1266-M1270.

Yoke-Kqueen C, Learn-Han L, Noorzaleha AS, Son R, Sabrina $\mathrm{S}$, Jiun-Horng S, Chai-Hoon K. Characterization of multipleantimicrobial-resistant Salmonella enterica subsp. enterica isolated from indigenous vegetables and poultry in Malaysia. Lett Appl Microbiol 2008;46:318-324.

Yu T, Jiang X, Zhou Q, Wu J, Wu Z. Antimicrobial resistance, class 1 integrons, and horizontal transfer in Salmonella isolated from retail food in Henan, China. J Infect Dev Ctries 2014;8:705-711.

Zhang H, Li X, Yang Q, Sun L, Yang X, Zhou M, Deng R, Bi L. Plant growth, antibiotic uptake, and prevalence of antibiotic resistance in an endophytic system of Pakchoi under antibiotic exposure. Int J Environ Res Public Health 2017;14:1336.

Zhu B, Chen Q, Chen S, Zhu YG. Does organically produced lettuce harbor higher abundance of antibiotic resistance genes than conventionally produced? Environ Int 2017;98:152-159.

Zurfluh K, Nüesch-Inderbinen M, Morach M, Zihler Berner A, Hächler H, Stephan R. Extended-spectrum- $\beta$-lactamaseproducing Enterobacteriaceae isolated from vegetables imported from the Dominican Republic, India, Thailand, and Vietnam. Appl Environ Microbiol 2015;81:3115-3120.

Zurfuh K, Poirel L, Nordmann P, Nüesch-Inderbinen M, Hächler H, Stephan R. Occurrence of the plasmid-borne $m c r-$ 1 colistin resistance gene in extended-spectrum- $\beta$-lactamaseproducing Enterobacteriaceae in river water and imported vegetable samples in Switzerland. Antimicrob Agents Chemother 2016;60:2594-2595.

Address correspondence to: Christina Susanne Hölzel, PhD Institute for Animal Breeding and Husbandry Christian-Albrechts-University Kiel (CAU) Hermann-Rodewald-Str. 6 $24098 \mathrm{Kiel}$ Germany

E-mail: choelzel@tierzucht.uni-kiel.de 